\title{
O modelo semiótico nos estudos literários
}

\author{
Matheus de Brito" \\ Fabio Akcelrud Durão"
}

\section{Resumo}

Devido a especificidades que acompanharam a profissionalização e a academização dos estudos literários no Brasil, o sentido tomado pela noção de sentido foi quase unanimemente semiótico. Falar de sentido, assim, equivale a pensar em signo. No entanto, diferentemente de "referente", por exemplo, que imediatamente invoca um contexto linguístico, o sentido pode ser pensado de outras maneiras. A persistência do modelo semiótico, tanto como mentalidade quanto jargão, está na base de vários problemas que marcam os estudos literários brasileiros atuais. Outra noção de sentido e uma diferente atitude conceitual em relação à obra literária podem oferecer saídas para muitos desses problemas.

Palavras-chave: Sentido. Estudos Literários. Teoria Literária.

\section{Introdução}

É notável o processo de recessão dos esforços por construir modelos teóricos para a Literatura, uma tendência que seguramente acompanhou a generalização da crítica dos anos 1960 e 1970 às explicações totalizantes da Modernidade filosófica. Em vez disso, junto à palavra-de-ordem da inter/trans/pós-disciplinaridade, hoje paira um anátema sobre as pretensões de adequação e universalidade da Teoria à Literatura. Essa destotalização teórica registra, porém, uma espécie de contradição performativa: de uma perspectiva conceitual, a complexidade

Doutorando do programa Estudos Avançados em Materialidades da Literatura (Faculdade de Letras da Universidade de Coimbra) e do programa Teoria e História Literária IEL-Unicamp, sob regime de cotutela. E-mail: debrito@gmx.com

** Doutor pela Duke University (EUA, 2003) e livre-docente (2014) vinculado ao Departamento de Teoria Literária da Universidade Estadual de Campinas. E-mail: fabio@iel.unicamp.br 
dos objetos culturais impõe um óbice a qualquer intenção de univocidade que se lhes postulasse; porém, considerado o aspecto doutrinário da prática acadêmica, uma premeditada recusa da univocidade acaba por apagar a possibilidade mesma de medir as particularidades do objeto, isso é, aquilo que nele abre à diferença. Se essa aporia conceitual - a intenção de universalidade - foi cancelada em sua negatividade, com ela se perdeu a intenção oblíqua, indireta, de fazer surgir o heterogêneo: assim, a multiplicidade teórica surge como suplemento de uma experiência unidimensional do fenômeno literário. $\mathrm{O}$ atual clima de ausência de confrontos - mais próximo à mesmidade do que à pax romana - entre as diversas abordagens coopera tanto com a proliferação de revistas e colóquios quanto com a reprimenda da crítica valorativa, preparando (e concretizando) uma crise ao mesmo tempo epistemológica e institucional.

Em grande medida, a crítica pós-estruturalista às limitações do estruturalismo do Círculo de Praga não abandonou a província do signo, mas acentuou-lhe aspectos criticáveis. Isso se deve sobretudo ao fato de que "estruturalismo" nomeia mais que uma metodologia e algo mais que uma tendência nas Humanas, uma espécie de forma mental cujos pressupostos epistemológicos se encontravam já na própria fundação da disciplina-piloto dos estudos literários. Comuns tanto a Saussure como aos Formalistas Russos, a quem se reporta a gênese da Teoria da Literatura, muitas das noções que detêm precedência lógica em relação à análise literária precisaram apenas de seu entrelaçamento histórico para que se consolidassem como língua franca das Letras. Apesar de suas insuficiências serem amplamente conhecidas, a persistência de seus pressupostos representa uma dupla ameaça: por um lado, o lugar irrefletido da disciplina nos atuais curricula ofusca o surgimento de novos interesses ou modos de experiência estética atualmente vinculados à atividade literária; por outro, a exaustão conceitual da Teoria conduz à prática acadêmica à rotinização e suscita discursos antiteóricos que, em última instância, trazem à luz a própria perda de evidência dos estudos literários em seu atual formato, não raro confundida com a perda de evidência da própria literatura.

Certamente, devido à inércia de nossos críticos, muito mais do que a algum mérito próprio, muito do discurso corrente sobre a natureza múltipla do fenômeno literário ainda ecoa o processo de redução à linguagem, como se todas as feições da experiência literária - de acordo com uma aposta pouco refletida numa definição metafórica da obra literária como algo "feito de" linguagem - fossem textos a analisar ou, pior, passíveis de desconstrução. A mensura dos problemas e dificuldades em que incorre uma noção demasiado estreita de literatura deve tornar claro que é esse substrato epistemológico que promove a rápida aceitação da semiótica 
e das linguísticas do discurso no contexto acadêmico brasileiro, em detrimento das alternativas, quer se trate do declínio da crítica histórica quer do pouco interesse até hoje manifesto por uma via especulativa, a exemplo da teoria estética. Porque hoje, mais urgentemente que legitimar a inflação interpretativa, cabe à teoria literária repensar seu papel, nosso esforço de revisitar o quadro histórico e conceitual em que surgem as reivindicações de cientificidade da crítica literária, a primeira deste trabalho, deve auxiliar-nos a compreender como foi que a análise literária converteu-se, sob a égide da academia, na atual análise semiótica e como esta se tornou paradigma para as Letras no Brasil, sendo essas a segunda e a terceira partes. Uma proposta corretiva, por fim, é a conclusão a que queremos chegar.

\section{Em busca de legitimidade}

Os primeiros esforços por fazer da crítica literária um exercício objetivo compartilham com o surgimento da linguística como ciência do mesmo ambiente ideológico e pressupostos epistemológicos. Com a profissionalização do escritor, que acompanhou a marcha de universalização dos meios de acesso à escrita (a difusão do ensino compulsório estatal $^{1}$ e da imprensa livre) e o surgimento do mercado burguês da arte no Século XIX, era propício o momento para a demarcação de fronteiras entre diferentes interesses em relação à literatura
(GUY e SMALL, 2000). A intenção de consolidar o espaço acadêmico da crítica foi o impulso inicial à formalização dos estudos literários; a isso serviu, como à linguística, uma ideia nomotética de ciência, conforme a qual a validade de um saber se determinava pela possibilidade de convertê-lo num sistema de proposições descritivas de validade universal.

Como disciplina acadêmica, que se pode difusamente remontar ao início do Século $\mathrm{XX},{ }^{2}$ a ideia de teorizar o fenômeno literário enraíza-se no quadro de crise das tendências positivistas nas Humanidades. Desde meados do Século XIX, as formas de materialismos que se podem associar ao Positivismo se viram confrontadas com um deslocamento do interesse intelectual para feições ou aspectos da experiência humana que não se reduzissem à verificação empírica e, com isso, à doutrina mecanicista das ciências da natureza. ${ }^{3}$ No meio literário especificamente, o historicismo positivista tornara-se sinônimo de biografismo e de causalidade reducionista porque restringira o estudo da literatura à prática de comentários temáticos e à especulação sobre o contexto de concepção de obras, normalmente em conformidade com algum programa cultural nacionalista ou, de qualquer modo, em função do prestígio do autor (GRAFF, 2007, p. 81-97). No final do Sécuclo XIX, essa prática se destacava e respondia à "crítica impressionista" que circulava em periódicos, essa ainda hoje sinônimo de 
subjetivismo e ausência de rigor. Essas são as coordenadas-limite - imprecações contra um conhecimento estéril e uma experiência limitada ${ }^{4}$ - em relações às quais a reivindicação de uma abordagem que produza conhecimento válido sobre o fenômeno literário, procurará manterse epistemologicamente equidistante no campo das Letras.

O que é um problema epistemológico também é, per se, ideológico. Que razão leva à intenção de produzir ciência conforme determinado critério? Que tipo de função social, na qualidade de ciência, se espera de um saber literário "válido"? Não é difícil associarmos as duas grandes tendências do comentário e da crítica jornalística a duas funções que se pode dizer que a literatura desempenhou ao longo do Século XIX: por um lado, coube-lhe proporcionar imagens normativas dentro do quadro de transformações históricas por que a sociedade industrial passava - imagens cuja elucidação e transmissão eram asseguradas pelo ensino acadêmico - e, por outro, funcionar como discurso compensatório para os problemas que surgiam com as mesmas transformações - a que o exercício da interioridade burguesa vinha em socorro (GUMBRECHT, 1998a, p. 153ss). A validade dessas práticas parece ter sido determinada desde fora pelo papel institucional que cumpriam, pelo interesse que elas evidenciavam, pela sua realidade prática ${ }^{5}$ - em suma, por elementos que fugiam, antes de um novo modelo científico, às noções estéticas que se con- solidaram conjuntamente com a relativa autonomia de que o artista burguês e a instituição artística se viram investidos com a substituição do velho mecenato pelo novo mercado (DAY, 2008, p. 162$168,265 \mathrm{ss}$ ). Qual era o pressuposto de falar sobre "literatura" sem remeter a um uso social, isto é, como se ela se sustentasse fora daquelas expectativas pública e normativamente embasadas ou do domínio da experiência privada? Naquele contexto, a reivindicação de uma "objetividade" literária surgia como consequência da trivialização de conceitos da teoria idealista da arte romântica. Ao mesmo tempo, a possibilidade de tomar o objeto literário como algo de singular indicava a parcial autonomização da crítica em relação às demais instituições sociais. Mas se a hipóstase de conceitos da estética implicava em certa perda de seu dinamismo crítico, autorreflexivo, de outro modo, a resultante axiomática idealista respondia de maneira consistente à profusão de opiniões diletantes a respeito de arte. Sendo esse um compromisso tácito entre estética e teoria, os novos critérios para a validade do conhecimento eram apenas uma forma de legitimar um discurso emergente, em certo sentido mais adequado às novas condições socio-históricas, mas em essência não menos ideológico que aquilo a que se opunha. ${ }^{6}$

O Século XIX, em que se consolidaram a Estética como filosofia da arte (SIMPSON, 2000) e a profissionalização do escritor e do crítico, foi também o que 
assistiu ao retorno das ideias de Kant como alternativa geral aos positivismos ${ }^{7}$ (FLACK, 2014) na ciência. A coerência discursiva produzida com o enlace entre a estética em voga e a epistemologia prestigiada conferia à nova crítica maior respaldo, sobretudo entre as gerações mais jovens, que testemunhavam a esterilidade do velho paradigma e sua incapacidade de lidar com os problemas cada vez mais complexos a que práxis artística se entregava. Ao mesmo tempo, porém, as garantias alcançadas pela aproximação à ciência emergente tinham implicações sérias para a subsequente construção da disciplina, a saber, uma progressiva desmaterialização do objeto literário. Com efeito, a crítica neokantiana ao empirismo levava das questões de natureza ontológica para as de natureza epistemológica, de perguntas pela coisa passava-se à inquisição das condições do conhecimento; como resposta ao clima de incerteza que se abateu sobre as ciências daquele século, o que se promovia assim era a estabilidade da subjetividade cognoscente contra a instabilidade da coisa a conhecer. Precisamente esse compromisso com a prioridade atribuída ao como epistemológico em detrimento do $q u e ̂$ ontológico é que é reificado no critério formal, no sentido de que o sujeito paradoxalmente projeta-o como atributo da própria coisa: não é que lhes interesse a condição do conhecimento ou do juízo literário, claro está, mas tornar esse saber comensurável com as próprias condições de constituição do objeto literário. ${ }^{8}$
Por seu turno, a intenção de universalidade associada à "ciência" assinalava também a possibilidade, senão a necessidade, de reconstruir o denominador comum de todas as manifestações literárias possíveis, e a fim de nomear essa coordenada transcendental cunhou-se a expressão literariedade. A Teoria da Literatura, ao postular uma espécie de universal como verdadeiro objeto disciplinar, acompanharia com isso a tendência geral das Humanidades no início do Século XX a se transformarem em "Ciências do Espírito", isso é, em saberes analíticos preocupados com dimensões comuns ou funções meta-históricas de que os objetos e práticas culturais eram os portadores ou resultantes ${ }^{9}$ (BEISER, 2011, p. 365ss). A construção teórica desses saberes, por mais distintas que fossem as áreas de aplicação, consistia num processo de abstração das especificidades dos fenômenos empíricos e na generalização dos seus elementos constantes. Segundo esse modelo, não apenas a "linguagem poética" foi pensada como resultado de um procedimento de afastamento da esfera da vida prática, seguindo a "autonomia" postulada pela estética idealista, mas seu próprio conceito, entendido como aspecto de uma estrutura transcendental, exigia $o$ afastamento metodológico da realidade empírica - novamente, a teoria reifica a especulação estética e funde-a ao programa da "ciência". 


\section{"Forma"}

O processo a que nos referimos é concomitante à adesão de um estatuto normativo à palavra-chave forma, que constituiria o "como" da ciência da literariedade. Forma definia muito vagamente, no discurso literário do Século XIX, uma condição ontológica da obra de arte (DOLEZEL, 1990, p. 89ss); já os modelos morfológicos românticos associavam-lhe tanto à constituição autônoma do poema (a tal organicidade imanente) quanto, com efeito, àquilo que nele está numa tensão dialética com seu fato linguístico bruto. Essa dissociação idealista, que visava banir da arte os seus rudimentos empíricos, foi precisamente o que se adotou como critério para a emergente "ciência" literária. A inovação russa, em relação aos velhos formalismos, consistiu em institucionalizar o veto ao juízo crítico que não se reportasse ao valor intrínseco da forma, a cuja autonomia já antes consentira. A intenção descritiva que caracteriza uma "ciência" não detinha prioridade sobre o compromisso estético. Isso implica dizer que a tarefa da crítica consistiria, antes de tudo, em pôr em evidência as características especificamente formais que mediaram a relação entre a obra e o fenômeno meta-histórico da literariedade ${ }^{10}-$ uma tarefa primariamente analítica. Nesse passo, a crítica deslocou-se de um espaço social geral - moral, ético, nacionalista ou qualquer que fosse seu horizonte de referências - para o lugar de enunciação propriamente estético-literário da análise literária.

Os pressupostos estéticos, associados à epistemologia neokantiana em voga e à rasura do horizonte axiológico que define a atividade judicativa, predispuseram a Teoria da Literatura à metodologia estrutural. O Formalismo já continha, sob a designação de "linguagem poética", de fato, a langue universal da literariedade e o conceito de signo literário como aquele cujo significado é a própria forma em que o universal poético se expressa, como negação sistemática da "linguagem prática". Foi essa tautologia que surgiu aos olhos de outros críticos literários como uma excentricidade e que, com efeito, cunhou a expressão pejorativa formalista. Com o apagamento do referente, pela rejeição daquilo que se julgou exterior ao sistema, e sua ênfase à constituição transcendental da literatura, e, com isso, ao primado da análise do texto sobre o comentário histórico e sua precedência sobre o juízo crítico, o que segue daí parece bastante menos conceitual que o quadro preliminar de emergência da Teoria: desde o início permaneceu autoevidente que a obra literária tem por material primário a linguagem e, com isso, sua ciência deve acompanhar os avanços da ciência linguística - a "linguagem poética" mais tarde sendo definida como mera codificação linguística. $\mathrm{O}$ que era um argumento estético radicalmente materialista - a obra é feita de linguagem, não de ideias - tornou-se um meio de contrabandear uma visão linguística (da "forma") do poema. 
Claro, se "forma" literária era um conceito vago (WARREN; WELLEK, 2003, p. 179-180; WEITZ, 1971) e demarcava fundamentalmente um espaço a ser ocupado por uma espécie de "suplemento" ao processo de comunicação (GUMBRECHT, 1998b, p. 300-301), ela não poderia ser facilmente integrada a um discurso que argumentava sua legitimidade pelo apelo à condição de ciência. Foi no esforço de especificar as coordenadas da literariedade que $o$ formalismo, como substrato teórico, se entrelaçou à metodologia estruturalista. Aqui, onde caberia perguntar o que é que os estudos literários efetivamente ganham ao conceber a literatura como linguagem, deve-se pensar no que efetivamente perdem, em última instância: o crítico não se apresenta mais como mediador da cultura, em amplo sentido como mediador de valores, mas como técnico que opera um objeto transcendental desprovido de qualquer particular resistência empírica - um objeto ao qual, uma vez recalcado o problema do interesse do conhecimento, quaisquer funções ou conteúdos poderiam ser imputados. Crítica declinou em juízo sobre a adequação do objeto a critérios prévios, ${ }^{11}$ promovendo a rotinização da análise literária.

\section{Da análise literária à semiótica}

As práticas do comentário histórico e da crítica subjetivista cederam à análise formal, pretensamente objetiva, do poema, a qual foi determinada por um compromisso estético-epistemológico que consolidaria ou legitimaria certo discurso junto à academia. Mas quais são as implicações da posterior semioticização das letras? Se formalismo é um nome para esteticismo em meio à crítica literária, isso significa que ele herda um aspecto particularista que não lhe permite ser reintegrado ao critério de universalidade de uma disciplina como a linguística. ${ }^{12}$ Com bases epistemológicas muito parecidas, porém, a teoria de Saussure teria influenciado o programa russo desde sua gênese (BOUISSAC, 2010, p. 128), predispondo-o ao estruturalismo que o Círculo Linguístico de Praga desenvolveria na posterior década de 1920. É importante entender essa passagem para pensar na institucionalização da disciplina acadêmica da Teoria Literária. Brevemente, essa institucionalização se pode reportar à migração, durante a II Guerra, do formalismo eslavo para os Estados Unidos, onde se articularia com um discurso crítico que se desenvolvia no ambiente intelectual da filosofia analítica anglo-americana, o New Criticism (BECK, 2001, p. 58).

A razão mais óbvia para a transformação dos conceitos estéticos em definições linguísticas é a operacionalidade das últimas em comparação com a resistência intrínseca aos primeiros. Pensar um conceito é pensar a realidade empírica junto à qual ele nasce, seu substrato ou intenção ontológica, suas contradições; a definição, em contrapartida, funciona 
num plano razoavelmente menos complexo. Se dada definição não serve à operação, empreende-se outra e outra, até que o sistema, fechado sobre si próprio, adquira consistência. Se dissemos que o primeiro grande erro da Teoria Literária foi assumir um compromisso ideológico com a ciência sem refletir o suficiente sobre o que isso implicava para sua intenção estética, o que lhe levou a hipostasiar suas construções teóricas como condição para sua autonomia, o segundo erro será assumir como autoevidente a natureza linguística da literatura e, com isso, avançar o comércio entre os dois domínios. Mas isso promoveu a desestetização da literatura: se, por um lado, estética parecia pressupor uma dimensão ontológica positiva para o fenômeno literário, sem a qual especular sobre arte e literatura não "faria sentido", por outro, a ciência da época tendia a recalcar o problema ontológico, empírico, em nome da possibilidade de construir um sistema lógico. Com a transposição de conceitos em definições, de estética em linguística, da especulação em fechamento teórico, sendo essa a condição de sustentar-se no espaço acadêmico, que noções passariam a integrar o discurso sobre literatura e quais suas consequências?

Em primeiro lugar, para superar o esteticismo formalista, a literatura foi transferida para o domínio da significação. As discussões pre-kantianas a respeito do estatuto ontológico de uma obra de arte ficavam entre tomar a obra por representação do mundo ou por expressão de um estado de coisas, fosse um indivíduo particular ou uma época. A oclusão do referente começou, porém, com o encanto romântico pela forma. $\mathrm{O}$ problema no Século XX ressurge quando a noção idealista de "forma orgânica", a autorrelação do poema, é orientada à semiótica, isso é, quando a "forma orgânica" é tornada "forma significante". Por resultado, a obra passou a funcionar como "significante" para um "significado" (redundantemente) literário. Se a noção originária visava livrar a literatura de compromissos estranhos à sua natureza estética, absolutizar a autonomia do processo de significação é reificar o que seria "estética". O texto semiótico não funciona, por exemplo, como um documento dotado de índices socio-históricos cujo conhecimento é imprescindível para sua leitura ou, inversamente, para as quais ele é o meio de acesso. O caso-limite do documento histórico é a necessidade da interpretação como resultado da perda de evidência das condições de comunicação, devido ao afastamento temporal ou de outro tipo. A orientação semiótica, porém, recusa uma "atitude natural" de leitura porque concebe mesmo o texto mais óbvio como portador de um diferimento constitutivo, uma disjunção sincrônica entre sua superfície material (a ser transposta pelo ato interpretativo) e seu conteúdo ou estrutura "profunda"; noutras palavras, porque, recalcando a dimensão estética na semiose, ela se põe na posição de assombro teórico perante $o$ fato de que algo que foi concebido como só 
representando e exprimindo a si mesmo é, enfim, capaz de comunicar ou produzir efeitos de sentido ou referência. A melhor exegese semiótica de um texto literário apenas mostrará como ele mesmo é uma instância da teoria semiótica do texto.

Uma vez que seja fundamentalmente autorreferencial, a concepção de literatura como estrutura meta-histórica leva à produção de conhecimento anistórico. Nem mesmo a um crítico como Antonio Candido (1996) ocorreu que a posição secundária do saber histórico em relação à atividade interpretativa provocaria, na verdade, o apagamento da história sedimentada no texto. Os "conteúdos" ou "materiais" dialogam irredutivelmente com contextos históricos particulares, mas o conteúdo $d a$ forma per se é extramundano, já que, como ao signo na langue de que a linguagem poética é a negação, lhe é igualmente vetada qualquer positividade. Embora aqui resida a boa intuição de que o valor epistêmico das propriedades formais é não idêntico e incomensurável com a semântica do texto - isso é, de que o fechamento da obra é uma forma epistêmica própria, que estética é uma função cognitiva não proposicional -, a ideia de que o sistema funciona por diferenças recíprocas entre os elementos degenera na de que não somente uma obra literária é determinada por leis como a própria transformação histórica da literatura depende da imanência de fatores literários - reduzindo aquela não identidade, a tensão que põe em curso a mudança, ao silêncio da pura diferencialidade. Na literatura não há mudança, mas apenas variação, série, jogo: a temporalidade da estrutura só conhece a passagem imperturbável de um elemento a outro (JAKOBSON, 1970). Se a diacronia de Saussure permitia que a exterioridade social influenciasse o desenvolvimento de uma língua - por exemplo, o arbitrário fato de uma variante prestigiada prevalecer sobre outra no curso do tempo -, a literariedade não conhece exterioridade concreta. O sistema, que imprime sobre todos os elementos seu caráter de necessidade, não tem autor ou leitor como agentes históricos, mas como elementos internos (autor-modelo, leitor-modelo, emissor e receptor, funções da comunicação, o demais jargão) do processo. A recusa abstrata do velho historicismo com isso produziria uma nova abstração da história literária: sob o regime estruturalista, historicizar consiste em pensar determinado registro estilístico (significante) como necessidade estrutural de determinado gênero (significado), sem que se atente ao aspecto particular, histórico-social, mas assemântico, que é imanente àquela forma ou procedimento. O primado da análise literária sobre a história apaga os lugares de enunciação do texto e, inevitavelmente, da própria atividade interpretativa.

O terceiro problema surge, portanto, da erradicação do horizonte pragmático e axiológico da crítica literária. Se a literatura significa a si própria e sua dinâmica se desdobra por sua própria 
força, sua razão de ser se torna pouco evidente e, ao mesmo tempo, demasiado autoevidente. Pouco devido ao fato de ela não dizer nada por si mesma, como estrutura, a respeito do ou para o quadro socio-histórico em que existe; demasiado porque, ao mesmo tempo, enfatiza-se irrefletidamente sua óbvia capacidade de significar, isso é, de produzir significados. Essa equação de estrutura e significação, isto é, de forma e informação, mistura-se perniciosamente à "objetividade" da teoria e ao desinteresse pragmático do crítico, redobrando a desqualificação da obra empírica ainda num outro sentido: se não consiste na exploração do potencial estrutural de significação, se não apresenta uma "saturação semântica", se sua forma não é "significante", se ela, em suma, não participa do jogo da comunicação, então a obra não é interessante - ela só o é se falar a linguagem da análise. Por outro lado, uma boa análise, como curadoria da significação, é aquela que cumpre o imperativo acadêmico de fazer a literatura falar a qualquer custo: não interessa o quanto a forma de uma obra passiva ou ativamente se opõe à significação, quanto mais uma obra se recuse a comunicar sentido, mais intensamente sua própria disrupção comunicativa será intimada a falar.

Para qualquer caso, a concepção de um "texto em si" como um objeto desprovido de subjetividade - seja o vestígio da intenção autoral na obra, seja a obra como sujeito per se - reifica ao mesmo tempo o fazer artístico e o fazer crítico. Se esse processo de dessubjetivação parece continuar a estética do desinteresse, que os românticos, acompanhando sua fé na organicidade da obra como lugar crítico, levantaram contra o utilitarismo burguês e a alienação provocada pelo avanço do capitalismo industrial na Europa, e se ela própria tomou parte noutro momento crítico, o da consolidação do lugar acadêmico da crítica literária, hoje se percebe como essa tendência à objetividade, sobrevivendo ao estiolamento da experiência estética, é não uma forma de explicar algo como o sistema literário mas de expor seu próprio lugar de enunciação: a violenta dialética conforme a qual seu desenraizamento histórico-social e sua desmaterialização asseguraram a forma mais pobre de sua integração social - sua subsistência acadêmica, sua participação no ensino obrigatório e na indústria da consciência. A estética romântica do desinteresse tornou-se a atual retórica acadêmica da inutilidade, cuja ironia é sua coincidência com a inverdade: a abolição da subjetividade, o apagamento do referente, o fim da história, a integração compulsória ao sistema - tudo concorre para o empobrecimento do objeto, da obra literária, exigindo e autorizando assim a atividade acadêmica mor, a produção de sentido. Após o descarte do sujeito e de sua objetividade histórica, nenhum interesse particular pode ser postulado, nenhuma dimensão estética que não se resuma a uma definição funcional ou nenhum sentido que tome parte 
na exterioridade mundana, nenhum uso concreto da literatura, nenhuma verdade no horizonte de referências. Ela, a coisa-em-si do texto, expulsa de si a possibilidade de uma experiência que não seja redutível à pretensa objetividade da semiose.

\section{"Jogo"}

As críticas feitas ao primeiro estruturalismo ocultaram o problema mais sério da análise literária, não se afastando da doutrina da prioridade do como sobre o quê ou o por quê, do abstrato sobre a coisa. Tome-se, de início, a noção barthesiana de texte (BARTHES, 1989) como construto do plano discursivo: com o texte, se o problema da subjetividade recalcada pelo estruturalismo encontra alguma compensação, isto é, na aparente autoridade de que o leitor se vê investido como articulador dos sentidos, não é menos verdade que a literatura - agora como prática e não como objeto - se vê ainda mais desmaterializada, anistórica e reificada. Em primeiro lugar, Barthes cunhou a noção como modo de apagar os vestígios referenciais que ele associava ao paradigma da "obra", grosseiramente concebida como fenomenalismo bruto da matéria, os quais legitimariam a autoritária doxa da academia francesa. Com isso, porém, em vez de ser como a obra tal como ele a concebe, material e historicamente localizável, o texte é em si uma estrutura - algo que, como ele diz, não se "mostra", mas se "demons- tra". Por fim, a recusa a um valor que não seja o propriamente semiótico - a capacidade de produzir (e não apenas portar um) significado - esquece-se de si própria como juízo de valor, isso é, oculta o sujeito que postulou que a produção de sentido é uma função textual primária. Se a obra, ao menos do que tem de inverdade, de inadequação, permite uma experiência crítica por parte do sujeito - como a que leva Barthes a formular o texto - o texte em si quer ser um dispositivo crítico, uma relação em que o sujeito é lançado. Assim, o interesse de Barthes em restituir a dimensão estética da prática literária, precisamente porque não dirige sua ofensiva à base sobre a qual o próprio edifício do texte estaria assente, é falseado: tudo o que o sujeito barthesiano do texto faz é confrontar-se com um processo de difração de sentido, expor-se a ele e retirar-se - crítica é simples mensura do processo.

A linguística estruturalista produziu, em decorrência de seu compromisso com o texto, a noção de intertextualidade, que poderia ser eficientemente abreviada como certa espacialização daquela diacronia intrassistêmica dos formalistas. Diferentemente, porém, de indicar que a variação do sistema tem uma natureza formal e à parte dos sujeitos empíricos (JAKOBSON, 1970), a intertextualidade surge como o nexo total do sistema enquanto algo assegurado pela prática dialógica da lecto-escrita, que inclui a enunciação no enunciado. ${ }^{13} \mathrm{Se}$, como no texte de Barthes, é acertadamente críti- 
ca a ideia conforme a qual não há texto original, singular ou completo, não o é a reiteração da interdependência radical dos elementos do sistema, uma interdependência que é, novamente, fundada no primado da produtividade semiótica. Com a produtividade de Kristeva, a literatura é devolvida à sociedade, mas a significação como processo autorrelativo é deslocada do signo - significar é relacionar um significante a um significado - para sua coexistência opositiva no sistema - significar é diferenciar-se. Com efeito, há que pensar não somente a resultante condição da obra como um mero intervalo no "jogo dos significantes" da intertextualidade, mas o fato de que a equação entre texto (aqui não o texte barthesiano, mas o simples texto literário) e discurso implica que o sujeito da enunciação é que é produzido em conformidade com a lógica da significação - ele é definido como sua própria atividade comunicativa e devolvido à sua "perspectiva" enunciativa. Essa espécie de textualidade total só é possível porque assume de antemão o caráter transcendental, constitutivo e irredutível, da linguagem em relação à experiência humana - nenhum conceito poderia ser pensado contra a própria linguagem.

Em certo sentido, um dos principais traços da lógica do texto pós-estruturalista é a transformação da semiose como relação relativamente "estável" entre um significante e um significado, na relação infinita entre um significante e outro significante. É possível explicar, com isso, um terceiro elemento corrente dos atuais estudos literários: o fetichismo da polissemia. Se, por um lado, a feição polissêmica é o caso típico da linguagem - que antes mesmo de qualquer intenção artística conhece a metáfora, a metonímia, a analogia, etc. - e, por outro, essa função é valorizada como um aspecto distintivo da arte literária de acordo com a forma pela qual se realiza, o caso fetichista da polissemia pertence mais à esfera da prática acadêmica do que constitui um "polissemismo" que pudesse ser atribuído ao objeto literário. Não se trata apenas do texto a analisar ser "semanticamente saturado" ou imanentemente instável, mas do esforço do crítico em dispersá-lo, remetê-lo para todos os lados possíveis, para todos os sistemas de significação, códigos, regimes por meio dos quais ele puder perscrutar objeto, em confirmar fielmente a exuberância que ele pressupôs para o texto e para sua própria atividade de leitura. Não é difícil associar essa espécie de prática - que se vê confirmada pelo simples fato de que qualquer enunciado existe sob a ameaça de seu desmentido, ao mesmo tempo em que se assume que a instabilidade imanente ao processo comunicacional é por si só um convite à oposição - a um aspecto aparentemente contraditório do discurso crítico contemporâneo: a asseveração da inutilidade selvagem da literatura. A função libertadora do que se conceituou como um processo de pura autorreferência sem valor empírico faz-se precisamente acompanhar da 
proliferação interpretativa, da arte pela arte da exegese - como se a semiose "sem objeto" do texte barthesiano provocasse um autêntico horror vacui acadêmico. Não raro essa desmultiplicação semiótica é mimetizada pela retórica da própria crítica, na condição de o discurso acadêmico ter ilegitimamente atribuído a si as funções que outrora postulava para a linguagem literária: o compromisso que o crítico assumiu de antemão com aquela multiplicidade não se encontra nem mesmo na obra abordada, mas se cristaliza no fraseado de mau gosto e numa paronomásia incansável, numa clara tentativa de compensar (ou ofuscar) a inocuidade de suas considerações ou mesmo a qualidade duvidosa da obra. O mais surpreendente, no quadro apoteótico da semiose, seria talvez algo simplesmente ter o sentido que tem e não mais.

Se a cooperação entre teoria literária e estruturalismo, apesar da contradição imanente à sua tarefa, visava dar continuidade ao processo de desmistificação do fenômeno literário e de crítica da autoridade cultural, a generalização pouco ou mal refletida de algumas de suas noções não deixou de se erguer numa nova estética (ou mesmo religião) da estrutura e nova normatividade. A compatibilidade discursiva entre as bases epistemológicas da Teoria da Literatura e os postulados estéticos que definem mesmo o seu objeto é desmentida pela incompatibilidade conceitual de duas intenções distintas: por um lado, a estética como síntese de experiência e saber especulativo, e, por outro, uma concepção analítica de ciência, influenciada pelo neokantismo. Isso desencadeia um processo de complexificação de resultados ambíguos, já que, se a insolubilidade do problema central da Teoria foi seu melhor meio de sobrevivência institucional e intelectual - na formulação de De Man, "teoria" é um processo infinito de autorrelação negativa -, a atividade crítica não deixou de tomar parte no processo de reificação social, produzindo um discurso que, cada vez que se inclina criticamente sobre sua própria inadequação, contribui com a desreferencialização e desistoricização, a dessubjetivação e o empobrecimento da própria experiência estético-literária. Mesmo sua crítica, persistindo em tomar por critério de validade a semiose, herda junto a seu aparato conceitual a capitulação perante a história no mesmo instante em que oculta o empobrecimento radical a que a experiência é hoje submetida. Essa é uma deficiência epistemológica e ideológica que não deixa de se reproduzir nas humanidades, apesar do atual demérito do estruturalismo.

\section{A condição da academia no Brasil}

As Letras parecem fadadas a reproduzir uma consciência ingênua em relação à literatura. $\mathrm{O}$ pressuposto fundamental da crítica acadêmica é a dissociação entre uma dimensão privada, pessoal e arbitrária, da experiência literária e uma 
dimensão pública, em que o discurso crítico funcionaria conforme regras postuladas pelo "objeto" (daí a pretensão de "objetividade") ou prescritas pela comunidade de especialistas. ${ }^{14}$ Essa separação teve a função de promover a autonomia do profissional imputando-lhe uma relação idêntica à que o burguês mantinha com o mercado, senão mesmo idêntica à alienação entre o trabalhador e o produto. $\mathrm{O}$ acrescentamento de um momento social ao juízo crítico, os esforços por politizar os estudos literários e a abordagem temática dos cultural studies são, por exemplo, tentativas de remediar esse hiato, que demarca na literatura os limites da recepção das obras e da sua "objetividade". Sob a crítica da cisão entre a atividade literária individual e a realidade social em que ela se constitui, isto é, como impulso à tematização do autor/leitor e seu lugar socio-histórico, opera a consciência da crise por que passa a literatura, devido à progressiva perda de evidência de seu papel social. Uma vez aceite, porém, o falso o pressuposto, reelaborá-lo em seus próprios termos é o mesmo que ratificá-lo: seus efeitos não foram radicalmente contestado. A dificuldade depende de fatores peculiares ao quadro epistemológico e socio-histórico do desenvolvimento dos cursos de Letras no Brasil.

No Brasil, o programa de academização da crítica se iniciou nos anos 1950 com as injunções de Afrânio Coutinho contra a crítica jornalística, mais logo sendo introduzida a reflexão teórica sobre literatura nos currículos brasileiros, também em grande medida sob influência de Antonio Candido ${ }^{15}$. Se desde sua introdução, esse modelo já apresentava uma dívida às tendências formalistas do new criticism, ele mesmo se consolidou junto ao progresso do estruturalismo na linguística (CÂMARA JR., 1967) e sua voga nas Humanidades em geral (COUTINHO, 2010 [1971]). A neutralidade axiológica associada à sua relativa solidez como programa científico permitiu ao estruturalismo tomar um impulso junto à reforma universitária promovida pela ditadura, de que dependeram o avanço dos cursos de pós-graduação em Letras no Brasil (SANTOS, 2002) e a profissionalização do intelectual ( LIMA, 2009). Isso não significa que, naquele contexto inicial, o estruturalismo não conhecesse críticos - a exemplo da polêmica entre Antonio Candido e Affonso Romano de Sant'Anna (CANDIDO, 1993) -, mas a insuficiência da crítica ao estruturalismo em conter sua voga não deve passar despercebida. Se a ditadura perseguiu o que lhe pareceu subversivo, favorecendo o estruturalismo/formalismo, isso também não explica por que outras abordagens - Ciência da Literatura Empírica, Estética da Recepção, que operam no hiato social acima indicado - não foram recebidas com tanto entusiasmo, não explica porque não caíram no jargão. Por que, assim, o paradigma estruturalista não foi sujeito a uma crítica decisiva? Por que ele proliferou? Por que é que sua mentalidade persiste para além dos exercícios linguísticos? 
O primeiro motivo, seguramente, é o fato de nossa intelligentsia ser tão recente e inexperiente quanto nossa academia como um todo. $\mathrm{O}$ desenvolvimento acelerado da universidade brasileira nos anos 1960 e 1970, atrelado diretamente à importação de intelectuais para o país e ao constrangimento tecnocrático da ditadura, não nos permitiu desenvolver bases conceituais sólidas para legitimar nossa própria atividade intelectual frente ao pensamento "estrangeiro" nem, tampouco, interromper o fluxo teórico do boom estruturalista daqueles anos. A sedimentação do hábito adesionista que hoje caracteriza o mosaico intelectual brasileiro foi favorecida pela ausência de uma autorreflexividade crítica forte. Esse hábito, todavia, tem uma história anterior à universidade da ditadura e marginalmente insere o Brasil na história da generalização do neokantismo (BRITO, 1997) - bastando tomar como prototípico Sílvio Romero, sucessivamente ligado a Comte, Kant e Spencer (REALE, 1999). Com essa disposição às ramificações da filosofia finissecular europeia, nossa ideia de ciência - de "ciências humanas" - já nos surgiria parcialmente homogeneizada no século seguinte: a vexação do substancialismo da ontologia e asseveração de um construtivismo cultural; uma metodologia que perpetua, em todos os seus pormenores, a cisão entre sujeito e objeto, método e coisa, junto ao imperativo do saber sistemático; por fim, a neutralidade axiológica, que em última instância provoca um hiato entre a academia e o interesse social, de que ela abdicou em seu processo de consolidação. $\mathrm{O}$ estruturalismo se desenvolveu sobre nosso provincianismo. Se esse paradigma surgiu nas humanidades europeias como saída de uma crise tão intelectual quanto institucional, em meio à qual disputou sua legitimidade com outros discursos, a facilidade de seu transplante para 0 Brasil deveu-se precisamente à ausência de oposições efetivas.

Sem vozes o suficiente discordantes, a ressonância entre a noção de ciência e o estruturalismo parece ter contido outras correntes teóricas. Não porque fossem radicalmente outros os seus pressupostos, mas antes, porque não alcançaram a relação ótima (ou tautológica) entre o saber resultante e o próprio método e, dir-se-ia, entre a atividade acadêmica e a contemporânea práxis. Mas como explicar, em contrapartida, o curto fôlego das críticas ao estruturalismo no Brasil? Ainda que se consinta que os currículos de Letras condicionam uma forma específica de relacionar-se à literatura, produzindo além disso uma língua franca e terminologia sofisticada para a crítica acadêmica, isso apenas permite pensar a razão institucional pela qual não houve uma recusa total da relação entre estruturalismo e teoria literária. Não se explica assim a pouca resistência que conheceu e o fato de que, apesar de hoje ser metodologicamente residual, seu jargão ainda seja operante. Por que a Teoria Crítica nos anos 80 ou a linguística 
do discurso de orientação bakhtiniana, volosinoviana, não funcionaram como oponentes radicais, como a princípio pareciam ser? ${ }^{16} \mathrm{O}$ divórcio assumido entre a objetividade do fato literário e a condição subjetiva cooperou com a ausência de um programa autorreflexivo radical, que expusesse a necessidade de criticar desde dentro a distância entre o discurso acadêmico e o não acadêmico. A diferença fundamental entre essas duas figuras diz respeito à forma como se relacionam com a literatura: o próprio especialista adota uma postura conceitualmente mediada e rechaça a reação espontânea, porque pouco elaborada, a uma obra literária. Com a pretensão de que só a sofisticação analítica alcança o que verdadeiramente está em causa no objeto, confere-se o primado de um interesse sobre o outro e reduplica-se na academia a depauperização da experiência real do sujeito - cuja participação, como se aprende de Candido (CANDIDO, 1996), só é autorizada na medida em que ele é domesticado. O método não só constitui, mas com efeito oculta a espoliação do sujeito contemporâneo (ADORNO, 2009): incapaz de uma experiência intelectual que ultrapasse, qualitativamente, os limites de antemão determinados, (uma incapacidade que incorretamente se atribui ao próprio sujeito), a única segurança que lhe resta é tomar parte no mercado do consenso e entregar-se à negociação em sua linguagem. É com isso um fantasma de objetividade o denominador comum do discurso crítico e do estruturalismo: o sujeito coletivo é sancionado contra o particular, a estabilidade metodológica substitui a experiência inconstante, a teoria da ciência encobre a reificação social. Sob o discurso da objetividade e do método, a academia constrói subjetivamente seu objeto. ${ }^{17}$

Da incomensurabilidade entre o discurso sobre crítica no Brasil e uma enunciação enfaticamente crítica, resulta um permanente processo de disfuncionalização do juízo qualitativo. No instante em que não só pusesse em causa, mas efetivamente cortasse o vínculo com $o$ programa de que o estruturalismo é a codificação mais refinada, o pensamento crítico seria outra vez expulso do ambiente acadêmico, que ainda equaciona validade e sistema. Mas, em nome da estabilidade do campo e do reconhecimento, a subtração das qualidades do sujeito concorreu também para a anestesia da crítica. A premissa é partilhada com o estruturalismo: o signo desprovido de subjetividade só pode ser remetido ao sistema de que faz parte, por isso o juízo crítico - assumindo o modelo do signo como a coisa em si - deve mimetizar essa objetividade morta. Se, como acabamos de fazer, essa formulação do princípio de imanência provoca o delírio taxonômico, nos estudos literários ela é simplesmente não verdadeira: no Brasil, a desqualificação crítica é tomada como mais-valia, especialmente porque contribui com a proliferação interpretativa; a exoneração do duplo trabalho histórico e crítico dos conceitos tanto promove a 
superprodução acadêmica quanto oculta a crise intelectual que acompanha a universidade brasileira como sua sombra.

\section{Conclusão, sobre reconsiderar a ontologia da obra}

Tanto quanto não é de admirar que, mesmo com o eclipse do estruturalismo e a rápida saturação do pós-, permaneçam não apenas seu jargão mas seu próprio hábito mental, seria ingênuo opor ao paradigma semiótico qualquer teoria alternativa, como também seria falso negar a sofisticação da atividade crítica e a validade institucional com ele alcançadas. Os atuais interesses críticos - ao menos aquele de se afastar do ventriloquismo - pressupõem, porém, uma suspeita crítica em relação a soluções conceituais, incluindo aí a afirmação abstrata da insolubilidade do significante no significado, do texto na leitura, e toda essa discussão que nos parece remeter a uma nova forma de impressionismo crítico gratuito. Mais importante é a reavaliação urgente da relação da teoria literária com aqueles aspectos subtraídos ao estudo da literatura, que uma concepção estética ainda priorizava. É preciso realizar uma autocrítica que se oriente conforme o ideal de restituição integral da experiência literária, o que implica considerar com propriedade o quê e o porquê da obra literária.

Do pós-estruturalismo indicamos que os postulados da significação difratada e da intertextualidade provocam um fetiche da polissemia, prolongando três pilares da primeira fase do formalismo-estruturalismo, a saber, a significação autorrelativa, a imanência do sistema literário e a organicidade do objeto. Se a primeira fase consiste num apagamento da subjetividade, que de imediato leva à deformação da obra literária, o segundo momento tende à discursividade inócua, uma apologia da multiplicidade e da variação que, ao mesmo tempo em que se insurge contra o hábito mecânico da análise de poemas, fica bastante aquém desse em relação à responsabilidade do estudo das letras. O difícil estatuto da linguagem literária, sempre diante do imperativo acadêmico de fazer falar a literatura, é em grande medida responsável pela confusão, sendo o nó entre o discurso estético e o discurso acadêmico das Letras. A transformação desse quadro se delineia na renovação do trabalho teórico em relação a essa "linguagem" e, à luz dessa nova reflexão, sobre o dever da crítica.

Em primeiro lugar, é preciso abandonar a noção unidimensional de literatura elaborada sob influência da linguística. Literatura e linguagem não são objetos de mesma natureza e, por isso, qualquer estudo parcial ou totalmente linguístico de uma obra literária será uma entrega sem reservas ao equívoco. Em grande parte a literatura poder-se-ia mesmo conceber como uma resistência ao processo de desencantamento da dignidade estética da palavra, que é o impulso que anima a ciência da linguagem - essa é a 
única forma em que o postulado kantiano do autotelismo da arte ainda pode e deve ser pensado hoje. $\mathrm{O}$ fato, além disso, de ter seu lugar bem definido no ambiente acadêmico permite que a crítica literária prescinda de uma discursividade "científica" e se aproxime outra vez de seu objeto sem o recurso a definições. "Estética" nomeia essa atitude do pensamento que gostaria de fazer justiça às coisas sem reduzi-las a critérios apriorísticos. Isso implica, por fim, que um momento ou aspecto da obra de arte literária não pode, como aconteceu à noção de "forma", deter o privilégio sobre os demais; se é preciso conceber a obra, ao menos como ponto de partida, como uma "totalidade", o modo como essa totalidade se constrói não pode ser teoricamente aduzido mas deve ser progressivamente pensado junto à obra.

Deve-se rejeitar, em definitivo, a ideia de que os estudos literários devem propiciar um saber objetivo seja sobre a história da literatura seja sobre o fenômeno meta-histórico da "literariedade", sim; mas não se deve com isso legitimar uma irracionalidade discursiva, sob a alegação de que tal conhecimento de caráter "imanente" não é possível, não se pode capitular da intenção de ir à coisa. $\mathrm{O}$ critério da crítica não é a ratificação de parâmetros a partir do processamento mecânico das obras - se elas são autorreflexivas ou semanticamente saturadas, se revolucionárias, se reproduzem a ideologia dominante, se sua forma é "orgânica”, etc. -, e muito menos o emprego das obras literárias como argumentos na “desmistificação" compulsória dos conceitos de que já desistimos há muito. $\mathrm{O}$ critério da crítica é o juízo de valor, que se mantém próximo à coisa em nome de seu interesse: uma obra consegue o que pretende ou não. A atividade crítica é a mediação desse interesse opaco e imanente à obra com o ambiente social e cultural de que o crítico participa - e, precisamente na medida em que participa dele, não precisa reivindicá-lo como suplemento ao trabalho analítico.

Se é verdade, como o lugar comum da teoria dos media, que a história dos homens pode ser valiosamente aprofundada por um estudo técnico dos meios de comunicação, dos quais dependem as mentalidades e, com isso, a ação coletiva humana, é preciso notar que a existência do sistema literário é antes um fator de complexificação dessa história. A literatura não se liga de maneira imediata à mentalidade de uma época e o fato de ser radicada na parole impõe um limite à sua abordagem sistemática; a única forma de compensar essa "dificuldade" comunicacional é mostrar-se atento à obra e permitir-se perceber o que nela não se reduz de imediato às expectativas teóricas, perceber o que nela provoca uma experiência. Trata-se aqui de deixar de isolar a obra em sua relação com o "contexto" de que faz parte para assumir que sua pertinência histórica não é algo que possa ser reconduzido a um programa de leitura. Experiência implica um modo de cognição que não abdica de seu momento sensório, afetivo ou intuitivo, que não o 
toma como uma simples "aproximação empática", mas como organon mesmo da atividade crítica. Uma atitude transformada em relação à condição objetiva da obra literária pode e deve fazer o esforço para sair das discussões sobre forma e semântica sem recair em qualquer forma de historicismo tosco.

Por fim, apesar de partirmos de um ideal metodológico, o da suspeita da metalinguagem, o fato de que a interpretação deva forjar, para cada ocasião interpretativa, os seus próprios instrumentos de leitura não significa, deve-se reiterar, o abandono do esforço conceitual. Ao contrário, a transformação do estatuto ontológico da obra literária implica que a própria interpretação deve ceder às suas exigências. Essas parecem, no atual contexto acadêmico brasileiro e no quadro mais geral da atual teorização literária, a necessidade de repensar a expressividade literária de uma perspectiva não linguística - noutras palavras, a adoção de uma perspectiva estética - e a de retomar uma doutrina do referente que possa ressituar a obra como coisa no mundo. Dotada de uma expressividade não linguística como algo de real no mundo, a questão evocada pela obra não seria a do seu sentido, mas do sentido mesmo desse - isso implica voltar a discutir o valor de verdade de uma obra, fazer juízos sobre a adequação entre a obra e o que nela provoca uma experiência. $\mathrm{O}$ conteúdo inteligível da experiência não se resume apenas ao registro semântico ou formal de uma dada época, mas inclui, em si, o potencial de sua própria época para a verdade.

\section{The semiotic model in literary studies}

\section{Abstract}

Due to specific facts that followed the academization and the professionalization of literary studies in Brazil, meaning took a sense utterly semiotic. To speak of meaning is thus equivalent to think of sign. However, unlike "referent", for instance, which immediately invokes a linguistic context, meaning can be thought of in other ways. The persistence of the semiotic model, its mindset as well as its jargon, is the basis of several problems concerning the current brazilian literary studies. Another account of meaning and a different conceptual attitude towards the literary work of art may provide solutions to many of these problems.

Keywords: Meaning. Literary studies. Literary theory.

\section{Notas}

1 É interessante a recontagem de Murray Rothbard, Education: Free and Compulsory (1999).

2 Essa observação poderia estender-se à poética romântica, fosse o caso de ter uma intenção "científica" particular. O período em que surgiu a Nova Crítica, em meados do séculos passado, com efeito, é o da institucionalização cabal da Teoria Literária, mas ela não foi decisiva para definir seus contornos epistêmicos, senão uma metodologia da análise literária. Outras alternativas, como remontar a Teoria a Aristóteles ou Platão são um capricho, senão uma tentativa ideológica de legitimar nossas disciplinas pelo apelo a uma suposta dignidade filosófica. Sobre o assunto ver Dolezel (1990). 
3 Esse quadro inicia com a crise de representação, se acompanharmos Foucault (1999), e se caracteriza pela reorganização epistemológica do pensamento europeu.

4 São os antagonistas do conhecido programa de Tynianov e R. Jakobson (1970).

5 A crítica impressionista, hoje tão facilmente criticável, fazia mais sentido em um ambiente no qual os leitores tinham mais leitura e não se pensava que a literatura poderia ser um meio de descoberta para coisas que nem ela mesma sabia que sabia.

6 Se consentimos com de Man (1986, pp. 106ss) o surgimento da Estética como uma consequente necessidade ideológica dos sistemas filosóficos, p. ex., em Kant como a necessidade de mediar entendimento conceitual e imaginação, podemos inverter o quadro e tomar o aspecto crítico que se conserva sob o momento "ideológico": o discurso estético, com a queda dos grandes sistemas, foi um dispositivo (mais ou menos) ingenuamente crítico. A emancipação da crítica, como instituição, define a possibilidade mesma de generalizar a atividade crítica.

7 François Dosse (1997, p. 30 ss), a propósito do estruturalismo, generaliza-lhe o "kantismo sem sujeito transcendental" com que Paul Ricoeur qualificou o método de Lévi-Strauss. Patrick Flack (2014) de maneira mais acurada, confirma a crescente influência neokantiana na academia russa a partir de 1900 e aponta sua epistemologia - não sua filosofia em conjunto, mas o método - como sólida base do Formalismo.

8 A transposição pode ser explicada de maneira simples: a subjetividade do processo é a forma, a posição de objeto é o "conteúdo". Se é possível dizer que o Formalismo Russo acompanha o racionalismo neo-kantiano que está na base do Estruturalismo, a teoria literária alemã - que parte da pergunta pelo conhecimento literário - acompanha a Fenomenologia, que descende do empirismo crítico da Escola de Marburg. É conhecida a influência da Escola de Baden sobre os intelectuais russos, no geral, e a participação do linguista holandês Hendrik Pos(1898-1955), de formação neokantiana, no desenvolvimento do estruturalismo. (CÂMARA JR., 1967; FLACK, 2013).

9 A supressão da premissa ontológica da cultura parece derivar da necessidade de justificar a especificidade das humanidades contra a imposição naturalista (empirista, positivista, materialista, etc.) do "método científico".
10 O claro paralelo a fazer aqui é o seguinte: forma funciona como um esquematismo kantiano, articulando o "conceito puro" da literariedade com a realidade empírica da obra. Boris Schnaiderman, assim, em sua apresentação aos textos coletados sob o título Teoria da Literatura da Ed. Globo, está errado ao mencionar uma dialética entre sincronia e diacronia. Só há alguma forma de dialética no esforço de pensar as transformaç̃es ocorridas, não pertencendo (a natureza dialética) ao sistema - este, como é pensado, determina diretamente seus componentes, sem que haja intervenção de fatores particulares no sentido de modificar a condição universal da literariedade. A precedência da forma na experiência estética não se deve confundir com seu primado sobre o cálice sagrado da teoria formalista.

11 A esse propósito Terry Eagleton (1994) propõe que a intenção da Teoria era tornar a literatura um substituto eficiente da religião, isto é, a atividade literária higienizada das velhas referências institucionais se prestava a um novo tipo, muito mais ideológico, de função social.

12 De Man (DE MAN, 1986) estende esse particularismo à toda Teoria da Literatura na figura de um "elemento pragmático" que não lhe permitiria ser reintegrada à "estética". A confusão se deve ao fato de que De Man atribui uma pretensão ontológica ou "objetiva" (RORTY, 1989) à Estética como parte de um sistema positivo, por oposição ao construtivismo ou à recusa ontológica de sua formulação da Teoria. Ele não leva em conta a possibilidade de uma teoria estética de orientação crítica, isto é, que resista a ser mais que simples mediação entre o domínio empírico e o conceitual.

13 Diana Luz Pessoa de Barros: "Os procedimentos de sintaxe do discurso já analisados permitem reconstruir a competência e a existência modal do sujeito da enunciação", contudo, "não se trata (...) de analisar o ser ontológico. Pretende-se refazer os caminhos narrativos do destinador-manipulador e do destinador-julgador, assim como os percursos temáticos de produtor e de receptor-interpretante, pelo recurso aos textos que formam o contexto do discurso em questão. Revê-se o problema do contexto em termos de relações intertextuais.”(2002, p. 140-142. ênfase original.). $\mathrm{O}$ que se entende pelo descarte do "ser ontológico" é sua comutação com o "ser semiótico", e do problema da cultura, senão mesmo da existência, com a intertextualidade. 
14 A esse quadro pertence o lugar comum da indisputabilidade do gosto, uma invocação regular do solipsismo e atomização social contemporâneos. Em grande medida, o ensino escolar de literatura contribui para o enrijecimento dessa oposição, tão real quanto não verdadeira, entre o profissional das letras e o simples leitor. Não verdadeira porque raramente empregue como uma crítica e sim como discurso consolatório (e consolidador) da tradição: o professor como preservador da herança cultural, por um lado, é o mais das vezes forçado a reconhecer a incomensurabilidade de sua relação tecnificada com a obra literária contra a disposição afetiva do aluno.

15 No mundo lusófono, os materiais referentes à teoria e à prática da análise literária, como então a concebemos, são já de meados ou final dos anos 60 (Aguiar e Silva em 1967, a Introdução de António Soares Amora e o Estudo analítico de Candido do mesmo ano, Massaud Moisés em 1969).

16 É importante notar que as práticas interpretativas que propuseram Afrânio Coutinho e Antonio Candido, embora de considerável impacto, não foram capazes de fazer frente ao movimento que chegava da França. De um lado, isso se deveu ao limitado esforço meta-teórico desses autores, preocupados com a explicação de obras específicas da literatura brasileira, que passaria então por uma reformulação abrangente. Em outras palavras, a formação de uma tradição literária brasileira impunha-se como tarefa primeira, com base sobre a qual elucubrações teóricas pudessem ser testadas. De outro lado, e como decorrência disso, nem Candido nem Coutinho inventaram conceitos novos, ferramentas de decifração que lhes fossem próprios.

17 A verdade da crítica de Fish (1980) ao ontologismo do new criticism, que era o reduto da dignidade estética da obra literária, é toda ela a seguinte: a fragilidade dos critérios escolhidos para determinar o que é cientificamente válido faz surgir, como seu elemento decisivo, a figura local da comunidade interpretativa que definiu as regras do jogo. Como na dialética do esclarecimento, o elemento permanente tem sua participação legitimada na lógica da identidade, enquanto aquilo que sucumbiu é descartado como a coisa sem mais razão de ser. Exemplo do que Adorno criticava como nominalismo vulgar, reconhece-se aí o que na verdade foi o reader-response criticism e mesmo a rezeptionsästhetik: a tentativa de aliciar o sujeito, ainda incapaz de ajuizar o que era qualitativa e objetivamente verdadeiro, a fim de reproduzir o círculo vicioso subjetivamente sancionado que, na qualidade de "comunidade", ditas as normas para a experiência do objeto.

\section{Referências}

ADORNO, T. Dialética Negativa. Rio de Janeiro: Jorge Zahar, 2009.

BARILLI, R. Ciência da cultura e fenomenologia dos estilos. Lisboa: Editorial Estampa, 1995.

BARTHES, R. From Work to Text. In: The Rustle of Language. Los Angeles, CA: University of California Press, 1989. p. 56-64.

BECK, J. Writing the Radical Center: William Carlos Williams, John Dewey, and American cultural politics. Albany: State University of New York Press, 2001.

BEISER, F. The German Historicist Tradition. Oxford: Oxford University Press, 2011.

BOUISSAC, P. Saussure: A Guide for the Perplexed. Londres e Nova York: Continuum, 2010.

BRITO, R. M. de. O Neokantismo no Brasil. Manaus: Editora da Universidade do Amazonas, 1997.

CÂMARA JR., J. M. O Estruturalismo. Alfa: Revista de Linguística, Marília-SP, v. 1 , n. 11, p. 43-88, mar. 1967.

CANDIDO, A. De cortiço a cortiço. In: $O$ discurso e a cidade. São Paulo: Duas Cidades, 1993.

O Estudo Analítico do Poema. São Paulo: Humanitas/FFLCH/USP, 1996.

COUTINHO, C. N. O Estruturalismo e a Miséria da Razão. São Paulo: Expressão Popular, 2010.

DAY, G. Literary Criticism: A New History. Edinburgh: Edinburgh University Press, 2008. 
DE MAN, P. The Resistance to Theory. Minneapolis: University of Minnesota Press, 1986.

DOLEZEL, L. A Poética Ocidental: tradição e Inovação. Lisboa: Calouste Gulbenkian, 1990.

DOSSE, F. History of Structuralism: the rising sign, 1945-1966. Minneapolis: University of Minnesota Press, 1997.

EAGLETON, T. Teoria da Literatura: uma Introdução. São Paulo: Martins Fontes, 1994.

FISH, S. Is There a Text in this Class? Cambridge, MA: Harvard University Press, 1980.

FLACK, P. Hendrik Pos and the epistemological foundations of structuralism. Disponível em: <http://hiphilangsci.net/2013/10/30/ hendrik-pos-and-the-epistemological-foundations-of-structuralism/>. Acesso em: 5 maio 2014.

. Between Literature and Philosophy: Russian Formalism and the Neo-Kantians. [no prelo], 2014.

FOUCAULT, M. As palavras e as coisas: uma arqueologia das ciências humanas. São Paulo: Martins Fontes, 1999.

GRAFF, G. Professing literature: an institutional history. Chicago: The University of Chicago Press, 2007.

GUMBRECHT, H. U. Corpo e forma. Rio de Janeiro: Eduerj, 1998a.

GUMBRECHT, H. U. Modernização dos sentidos. São Paulo: Editora 34, 1998 b.

GUY, J. M.; SMALL, I. The British "man of letters" and the rise of the professional. In: LITZ, A. W.; MENAND, L.; RAINEY, L. (Eds.). The Cambridge History of Literary Criticism, v. 7. Modernism and the New Criticism. Cambridge: Cambridge University Press, 2000. p. 377-388.

LIMA, L. C. Retrospecto de uma fresta. O que devo ao estruturalismo. Revista USP, São Paulo, v. 1, n. 81, p. 130-140, mar./maio 2009.
REALE, M. Sílvio Romero e os Problemas da Filosofia. In: ROMERO, SÍLVIO (1851/1914): Bibliografia e Estudos Críticos. Salvador: Centro de Documentação do Pensamento Brasileiro, 1999.

RORTY, R. Solidarity or Objectivity? In: KRAUSZ, M. (Ed.). Relativism: interpretation and confrontation. Notre Dame, Ind: University of Notre Dame Press, 1989.

ROTHBARD, M. Education: free and compulsory. Auburn, AL: Mises Institute, 1999.

SANTOS, C. M. DOS. Os Primeiros Passos da Pós-Graduação no Brasil: a Questao da Dependência. Ensaio: aval. pol. públ. educ., Rio de Janeiro, v. 10, n. 37, p. 479-492, out./ dez. 2002.

SIMPSON, D. Transcendental philosophy and Romantic criticism. In: BROWN, M. (Ed.). The Cambridge History of Literary Criticism, v. 5. Romanticism. Cambridge: Cambridge University Press, 2000.

TYNIANOV, J.; JAKOBSON, R. Os Problemas dos Estudos Literários e Lingüísticos. In: Teoria da Literatura. Porto Alegre: Globo, 1970.

WARREN, A.; WELLEK, R. Teoria da Literatura e Metodologia dos Estudos Literários. São Paulo: Martins Fontes, 2003.

WEITZ, M. The Content of Form: a commentary. New Literary History, v. 2, n. 2, Winter, p. 351-356, 1971. 